\title{
SEM Examination of Conductive Tissues of Pinus Koraiensis Needles
}

\author{
Zhu H. Ning, Xing Y. He, and Kamran K. Abdollahi \\ Chinese Academy of Sciences, Institute of Applied Ecology, Shenyang, China \\ Southern University, Urban Forestry Program, Baton Rouge, LA 70813
}

Korean pine (Pinus koraiensis) is a common urban tree species in northeastern China. It is a five needle cold tolerant tree with strong supportive root and shoot systems enabling the tree to withstand strong wind in urban areas. Its evergreen needles along with its beautiful cone shaped crown provides high aesthetic value especially during the fall and winter seasons when other urban trees shed their leaves. In order to grow better urban trees, one should understand their structure, function, and physiological processes. This paper reports the initial phase of the Korean pine study by examining the conductive tissues of the needles.

Needle samples were collected randomly from Korean pines and were sectioned and fixed over night at $4 \mathrm{C}^{0}$ in $4 \%$ glutaraldehyde buffered with a phosphate buffer at a $\mathrm{pH}$ of 7.2. After rinsing three times in the buffer, samples were dehydrated in a graded enthanol series and dried in a DCP-1 Critical Point Dryer, then coated in a Hummer II Sputter Coater (1). A Hitachi S-405A Scanning Electron Microscope was used for observations of the conductive tissues.

The cross sections of the needles revealed conductive tissues (FIG. 1). The major components of the conductive tissues were endodermis, transfusion tissue, xylem, and phloem (FIG. 1 and 2). The endodermis surrounding the transfusion tissue consisted of relatively thick-walled cells. Intercellular spaces were lacking among the endodermal cells and throughout most of the vascular region. The transfusion tissue surrounding the vascular bundle mainly consisted of two types of cells, living parenchyma cells with nonlignified cell walls, and thin walled but lignified tracheids. These two types of cells formed a continuous system to translocate water and food between the vascular bundle and the mesophyll tissue within the needle.

Within the vascular bundle, xylem was the principal water conducting tissue. The most characteristic component of the xylem was the tracheid. The tracheids had their secondary walls deposited in the form of spirals (helices) and had their ends overlapped each other (FIG. 3) The extension of the tracheids as a result of the needle growth pulled the helices far apart (FIG. 4). These helical thickening bands developed on the surface of the pitted secondary wall without covering the pits. Water thus mostly moved from cell to cell through pits.

Living parenchyma cells occurred in both xylem and phloem. They are particularly known for storage of food reserves in the form of starch or fat. Phloem tissue carries function of transporting food, mainly starch. The vascular system of the needle is connected to the vascular system in the stem through the system in the needle stalk. By the same token, the system in the stem (trunk) was connected with the system in the root. The entire conductive activities could occur within the tree body is mainly because of the existing connections among the conductive tissues.

Reference: (1) K. L. Klomparens et al., Procedures for Transmission and Scanning Electron Microscopy for Biological and Medical Sciences. $2^{\text {nd }}$ ed. Ladd Research Ind. Burlington, Vt. (1986) 


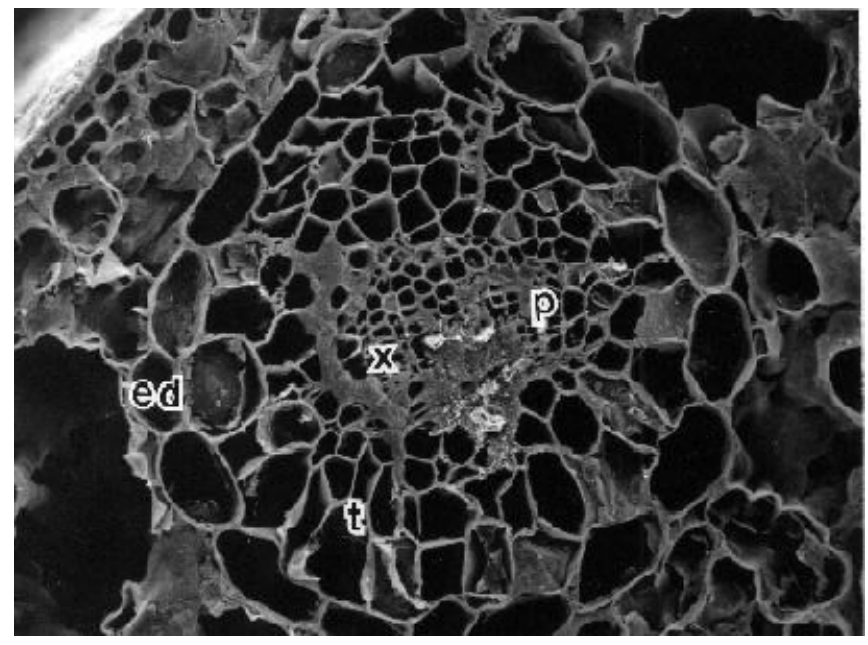

FIG. 1. Cross section of the needle shows the conductive tissues. ed, endodermis; $t$, transfusion tissue; $x$, xylem; p, phloem. x250

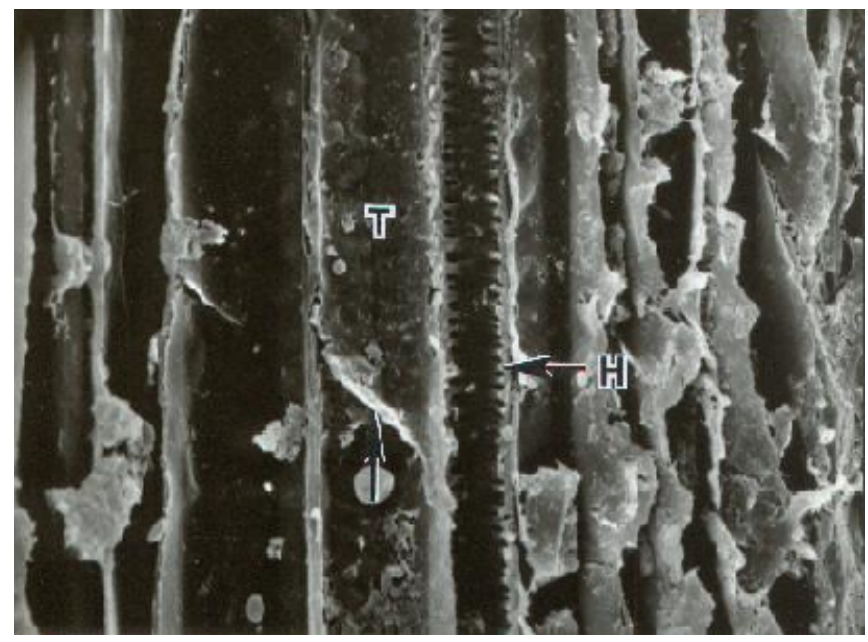

FIG 3. Longitudinal section of the needle shows the xylem tissue. T, tracheid; $\mathrm{H}$, helical (spiral) wall thickening of a tracheid. x1500

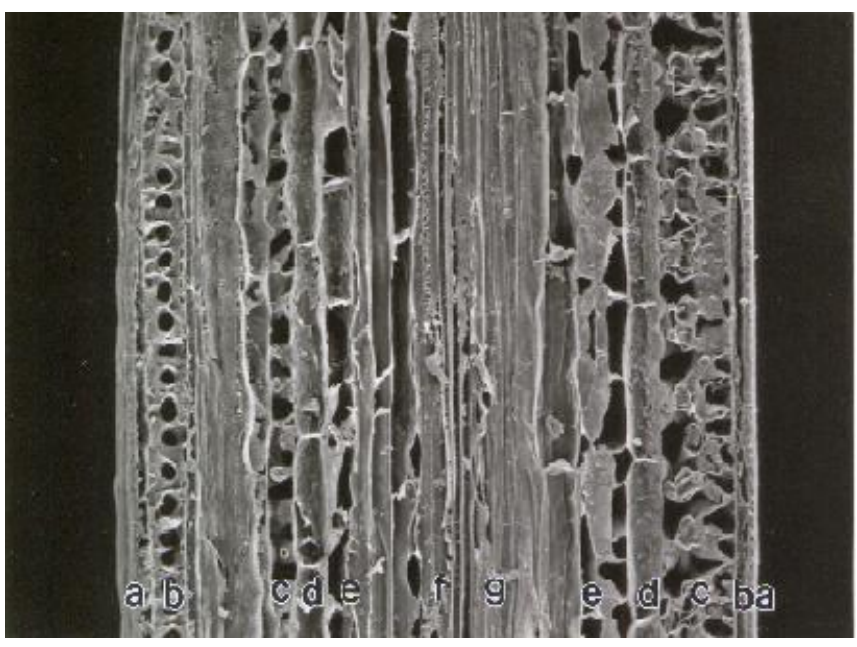

FIG 2. Longitudinal section of the needle shows the tissue types. a, epidermis; b, hypodermis; c, mesophyll; d, endodermis; e, transfusion tissue; f, xylem; g, phloem. x150

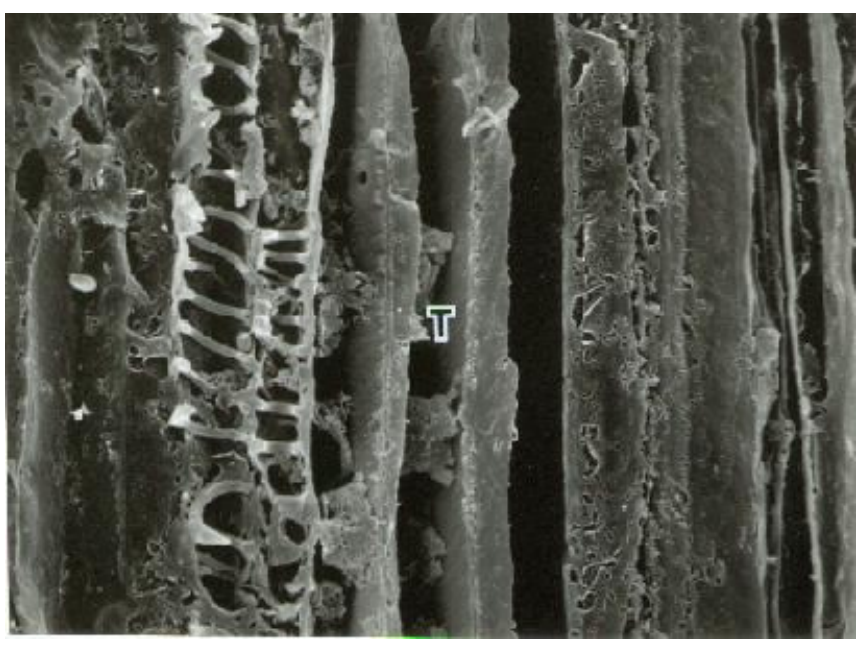

FIG 4. Longitudinal section of the needles shows xylem tissue. T, tracheid. Note the pit on the tracheid wall. $\mathrm{x} 1500$ 